\title{
Selected Reference Books of 1953
}

\author{
Miss $W$ inchell is reference librarian, Co- \\ lumbia University Libraries.
}

\section{INTRODUCTION}

4 GaIN, AS IN PREVIOUS ARTICles in this semi-annual series, ${ }^{1}$ this survey is based on notes written by members of the Reference Staff of the Columbia University Libraries. $^{2}$ In this issue, notes written by assistants and used unchanged are signed with initials.

As the purpose of the list is to present a selection of recent scholarly and foreign works of interest to university libraries, it is not necessarily well-balanced nor comprehensive. Code numbers (such as $\mathrm{D}_{7}$ and I P29) have been used to refer to titles in the Guide ${ }^{3}$ and its First Supplement.

\section{ARCHIVES}

Bautier, Robert-Henri. Bibliographie sélective des guides d'archives. Supplément au Guide international des archives, t.l (Europe), 1934. (In Journal of Documentation, 9:I-4I, March, I953).

A revised and enlarged edition of the Repertoire selectif de guides des archives issued in mimeographed form by Unesco in 1950. Lists guides to archival records printed in Europe from I934-I950 and outside Europe from I900-1950. Entries are listed under 76 countries and territories arranged alphabetically.

Particular attention has been given to industrial and commercial archives and to collections of photographic, radio and cinema materials.

${ }^{1}$ College and Research Libraries, January and July issues starting January ro52.

2 Mary Cunningham, Florence Gitelson, Olive Johnson, Kenneth I-ohf, Eugene Sheehy, and Beth Strong. ${ }^{2}$ Winchell, Constance M., Guide to Refercnce Books, 7 th ed. Chicago, ALA, I95I, First Supplement, Chicago, ALA, 1954.

\section{INDEXING}

Collison, Robert L. Indexes and Indexing: a Guide to the Indexing of Books, and Collections of Books, Periodicals, Music, Gramaphone Records, Films and other Material, with a Reference Section and Suggestions for Further Reading. London, Benn, I953. I 55p. IOs. 6d.

Discusses general indexing practices and their application to specific types of material. Includes a bibliography of books on indexing and a list of suggested reference works for the indexer.

\section{SOCIETIES}

Keeling, Guy W. Trusts and Foundations: a Select Guide to Organizations and Grant-making Bodies Operating in Great Britain and the Commonwealth, ed. by Thomas Landau. Cambridge, Bowes and Bowes, 1953. I94p. £2.2s.

Gives information about some Iooo foundations including, when possible: name, address, trustees, history, purpose, activities, conditions, grants, capital, publications, etc.

The main list is alphabetical. There are two indexes: I. classified (by Dewey Decimal Classification ); 2. alphabetical subject.

Appendix I, Government grants to voluntary agencies; Appendix 2, Bibliography.

\section{ENCYCLOPEDIAS}

Columbia-Viking Desk Encyclopedia, comp. and ed. at Columbia University by the Staff of The Columbia Encyclopedia. William Bridgwater, Editor-in-Chief. N.Y., Viking Pr., I953. I092p. il. $\$ 7.95$; thumb-indexed $\$ 8.95$.

A desk-size encyclopedia selected, condensed and rewritten from the Columbia Encyclopedia ( $G$ uide $\mathrm{D}_{7}$ ) by the Encyclopedia staff. Planned to give the American reader maximum 
information in small space with well-balanced coverage, emphasis is on contemporary facts and persons and on basic information in all fields likely to be needed by the contemporary reader. Inclusion of entries is as of April, 1953. Pronunciation gives accepted American usage. Full-page groupings of line drawings are new in this volume as are global and continental maps. Tables of certain subjects such as geologic eras, elements, and Nobel prizes, and lists of rulers, popes, titles of nobility, etc. add to its general usefulness.

\section{PERIODICALS}

New Serial Titles; a Union List ... Washington, D.C., Library of Congress, January I953- v.I, no.I- monthly.

Like its predecessor, Serial Titles Newly Received, this publication continues to list serial titles new to the collections of the $\mathrm{Li}$ brary of Congress not already listed in published union lists. Also to afford fuller coverage of serials new to American libraries, titles are now being reported by cooperating libraries. Whereas only the Library of Congress and the New York Public Library reported titles in the first issue, nineteen additional libraries participated in the July issue. Appearing in 12 monthly issues and an annual cumulation, this publication is similar to its predecessor in typography, format, and arrangement, and in its preparation the punched card method developed for the earlier list is followed. The list is prepared under the sponsorship of the Joint Committee on the Union List of Serials.-K.L.

\section{GOVERNMENT PUBLICATIONS}

Canada. Dept. of Public Printing and Stationery. Canadian Government Publications; Monthly Catalog. Publications $\mathrm{du}$ gouvernement canadien; catalogue mensuel. Ottawa, Queen's Printer, I953- no.I, Jan. 1953- , monthly.

This is "a comprehensive listing of all offcial publications, public documents and papers, not of a confidential nature, printed or 'processed' at government expense by authority of Parliament, or that of a Department, etc. of the government, including publications bought at public expense for use of, or dis- tribution to, Members of Parliament, public officials or the public." It is in two parts: I. publications in English and 2. publications in French. Both parts have four sections: I. Parliamentary publications (statutes, Senate, House of Commons, in that order), 2. publications of Departments, Agencies, Royal Commissions, etc., arranged alphabetically by the issuing body and then by title, 3. an alphabetical listing of periodicals, 4. an index to authors, titles, subjects and series, with crossreferences (entry-numbers are given, not pagenumbers). Full bibliographical details are given for each entry, except for the beginning dates of publication of periodicals. The price of each item is given, followed by a symbul indicating to whom it is available, and the code number used by the Supervisor of Government Publications. There will be annual cumulations.

The Monthly Catalog contains all the itens listed in the Daily Checklist during the previous month. (Neither of these includes the statutory orders and regulations: they appear only in Canada Gazette, Part II.)

This supersedes the Catalogue of Official Publications of the Parliament and Government of Canada, an annual with supplements monthly or as required, which was published from I927-I95I, and which gave sparse bibliographical information.-M.C.

\section{PHILOSOPHY}

Soares, Orris. Dicionário de filosofia. Rio de Janeiro, I952- v.I- (In progress)

At head of title: Ministério da Educação e Saúde. Instituto Nacional do Livro.

v.I, A-D

Includes biographical sketches, and definitions of terms, with etymologies, history, and references to sources. Some bibliography.

\section{PSYCHOLOGY}

Hinsie, Leland E. and Shatzky, Jacob. Psychiatric Dictionary with Encyclopedic Treatment of Modern Terms. 2d ed. with supplement. N.Y., Oxford Univ. Pr., I953. 78I p.

See Guide J13 for 1940 edition which is reprinted here without change. A Supplement, p.563-78I, lists some 900 additional terms culled from the recent literature of the subject. 


\section{RELIGION}

A Catholic Commentary on Holy Scripture.

Editorial Committee, Dom Bernard Orchard, Rev. Edmund F. Sutcliffe, Rev. Reginald C. Fuller, Dom Ralph Russell. Lond., N.Y., Thomas Nelson, 1953. I 3 I 2p. maps. \$I 5 .

Based on the current Douay Version but designed to be read with any other translation. There are general introductory articles to the whole work, to the Old Testament and to the New Testament, each signed by a scholar. The commentaries are also signed. Selective bibliographies include works by Catholic and non-Catholic authors. There is an extensive index.

\section{SOCIAL SCIENCES}

Lende, Helga. Books About the Blind; a Bibliographical Guide to Literature Relating to the Blind. New rev. ed. N.Y., American Foundation for the Blind, I953. 357p. \$5.

Ist ed. 1940. (Guide L25).

Revised and enlarged to include about 4200 annotated references, more than half of which were not listed in the first edition. General groupings are much the same with some variation in and additional subheadings. The main classes cover: work with the blind; education; psychology; vocations and economic adjustment; social adjustment; literature and reading; special groups; biographies and autobiographies; author index.

Mouvements ouvriers et socialistes: Chronologie et bibliographie. Collection dirigée par E. Dolléans et M. Crozier. Paris, Les Editions Ouvrieres, I950-53. [v.I-3] (In progress)

[v. I] Angleterre, France, Allemagne, Etats-Unis, I750-1918, [par] Edouard Dolléans et Michel Crozier. I950. 380p. I.400 fr.; [v. 2] L'ltalie, des origines à 1922, [par] Alfonso Leonetti. I952. I95p. $570 \mathrm{fr}$.; [v. 3] L'Espagne, I750-1936, [par] Renée Lamberet. 1953. 204p. $645 \mathrm{fr}$.

A fourth volume is to be devoted to Russia. Each volume is arranged chronologically by period. Under each period there is a chronology of events important to the labor movement followed by a bibliography listing documents, newspapers, books and pamphlets, including official publications. The first volume has an index of names cited, the other volumes have no indexes.

\section{Seckler-Hudson, Catheryn. Bibliography} on Public Administration: annotated. $4^{\text {th }}$ ed. Wash., American Univ. Pr., I953. I3 I p. \$3.50.

A selective bibliography of some I Ioo titles primarily in the field of national and international administration, with some materials on local administration. A classified list with author index. Only titles in the English language are included.

Special Libraries Association. Social Science Group. A Source List of Selected Labor Statistics. Rev. ed. N.Y., Assoc., I 953. I I 3p. \$2.

I950 rev. ed. (Guide L478.) This is the second revision.

Includes "those statistical series, published more than once a year, that tell a story about wages, hours, employment ... series on unemployment, labor force, strikes, labor turnover, labor costs, workmen's budgets, fringe benefits, and cost of living." Pref.

LAW

Price, Miles O. and Bitner, Harry. Effective Legal Research: A Practical Manual of Law Books and Their Use. N.Y., Prentice-Hall, i953. 633p. \$7.50.

A major reference work on legal research and bibliography which will be useful to librarian, teacher, student, and attorney. The main part is a manual discussing procedures and literature. Of particular value to librarians will be the chapters on special types of reference works, e.g., indexes, digests, encyclopedias, dictionaries, loose-leaf services, etc. A unique feature is the use of large and small type to differentiate the "must" reading from detailed amplification and historical notes. The chapter on "Standard legal citation forms" incorporates the essentials of $\mathrm{Mr}$. Price's A Practical Manual of Standard Legal Citation (1950).

The appendices include: American law reports and digests; British and Canadian ma- 
terial; a long list of Anglo-American legal periodicals, p.45 I-98, giving title, place of publication, period covered, and frequency (when possible); and a list of abbreviations commonly used in Anglo-American law, p.5 I I620. There are numerous illustrations of legal materials and a detailed index.

\section{EDUCATION}

Index Generalis; General Yearbook of Universities and of Higher Educational Institutions, Academies, Archives, Libraries, Scientific Institutes, Botanical and Zoological Gardens, Museums, Observatories, Learned Societies. Igth yr. I952-53. Paris, Dunod, I953. I673, $55 \mathrm{p}$.

Published annually for I 8 years, the Index Generalis now appears again for the first time since 1939. It is divided into six sections: universities and major institutions, observatories, libraries, scientific institutes, academies and learned societies, and indexes. Under each of the first four sections, institutions are grouped by countries arranged alphabetically. Universities and other teaching institutions in the U.S. are arranged alphabetically by name; for other countries, listing is by city. The academies and learned societies are arranged by subject of research and then by cities disregarding countries. The personal name and general geographical indexes lend to the usefulness of the book, but an institutional name index is lacking. A valuable feature of each entry is the inclusion of the date of revision of the information. The new edition lacks some of the special lists published in earlier editions (i. e., Nobel prizes, list of intellectual exchanges) and a general table of contents.F.G.

\section{PHILOLOGY}

Unbegaun, Boris Ottokar. A Bibliographical Guide to the Russian Language. Oxford, Clarendon Pr., I953. I74p.

Intended as a practical guide to publications dealing with the Russian language and its history, this useful volume lists I043 titles, many of them individually annotated, under three main divisions. Part I (General) includes works of a general bibliographical nature; Part II (Historical), those relating to the prehistory and history of the Russian language; and Part III (Descriptive), those on the grammar and vocabulary of modern literary Russian, plus works on dialects, slang, jargons, etc. The text is limited to brief remarks calling attention to the outstanding works in each subdivision and noting those areas and aspects for which there is no adequate coverage. Only scholarly works are included, outdated and superseded items being mentioned only as things to be avoided. Titles are given in full and in the original language. There is an index.-E.S.

Royal Society, London. The Transliteration of Russian, Serbian and Bulgarian for Bibliographical Purposes. London, Royal Society, I953. I2p. Is.

A new system of transliteration devised by the Royal Society and to be used in its publications. Based on criteria of unambiguity, simplicity in indexing, use of only those diacritical marks available to English printers, and facility in showing pronunciation.

\section{DICTIONARIES}

Magne, Augusto. Dicionário etimológico da lingua latina. Famílias de palavras $e$ derivaçōes vernáculas. Rio de Janeiro, I952- v.I- (In progress)

At head of title: Ministério da Educação e Saúde. Instituto Nacional do Livro. v.I, A-AP.

For each entry, attempts to give definition, usage, classical source and Portuguese vernacular derivative. There is a bibliography, p.XI-LXXXI, and an index to Portuguese words.-K.L.

Országh, László. Magyar-Angol Szótár. Budapest, Akadémiai Kiado, 1953. I 444p. \$I 9.5O.

Added title page and preface in English.

"Contains approximately 88,00o Hungarian entry-words and their English equivalents." More up-to-date than the Bizonfly (Guide $\mathrm{M}_{3 \mathrm{O}}$ ) and Yolland (Guide $\mathrm{M}_{302}$ ). Omits much obsolete material contained in these dictionaries and adds many new words which have been developed in the last decades and particularly during and since the war. These include social, political, and technical terms, 
and words connected with sports and games. Differences between English and American usage are sometimes indicated.-K.L.

\section{MEDICINE}

United Nations Educational, Scientific and Cultural Organization and the World Health Organization. World Medical Periodicals. Les périodiques médicaux dans le monde. Periodicos medicos del mundo. Paris, Unesco; Geneva, WHO, 1953. 237p. \$2.

Lists 3908 "current medical periodicals ... all medico-biological periodicals regularly surveyed by certain abstracting agencies, and well-known medical journals which ceased publication during the period 1900-1950." Titles of periodicals devoted to pharmacy, odontology, and veterinary medicine are included. There are subject and country inindexes. Includes abbreviations for titles as given in the World List of Scientific Periodicals (Guide Suppl. IN8).

Periodica Medica (4th ed., 1952) (Guide Suppl. I 29 ) listing I2,624 titles remains the most complete bibliography in the field.

\section{LITERATURE}

Cook, Dorothy Elizabeth and Monro, Isabel Stevenson. Short Story Index; an Index to 60,000 Stories in 4,320 Collections. N.Y., Wilson, I953. I553p. Service basis.

"Supersedes the Index to Short Stories compiled by Ina Ten Eyck Firkins (I 923) and its Supplements (1929 and 1936)." Pref. (Guide $\mathrm{R}_{154}$ ).

Indexes by author, title, and in many cases by subject, some 60,000 stories published in I 949 or earlier. The list of collections indexed is given in Part II, by author and title.

Cotton, Gerald Brooks and Glencross, Alan. Fiction Index ... Lond., Association of Assistant Librarians, 1953. 223p. 30 .

Subtitle: A guide to over 10,000 works of fiction, including short story collections, anthologies and omnibus volumes, most of which have been published, re-published or re- issued since the war, arranged under 2000 subject headings with numerous references, and intended for use in public and circulating libraries, schools and bookshops and by the general reader.

Covers the period between midsummer 1945 and 1952. Gives brief author and title only, without dates or publishing information.

\section{Gregor, Joseph. Der Schauspielführer.}

Stuttgart, Hiersemann, 1953- v.I, 375p.

This guide to more than one thousand years of German drama consists of outlines of individual works, with critical and historical notes for each. The first volume (274 plays) covers the period from the middle ages to Expressionism, each section being introduced by a short outline of the main features of the school treated; the second volume will bring the survey up to date. Indexes by author, title and date of first publication are useful features; there are also lists of monologues and duologues and a brief subject index.-O.J.

West, Dorothy Herbert and Peake, Dorothy Margaret. Play Index, I9491952. An Index to 2616 Plays in 1138 Volumes. N.Y., Wilson, 1953. 239p. $\$ 5$.

A new index which augments but does not supersede Firkin's Index to Plays and Supplement ( $G$ uide $\mathrm{R}_{136}$ ). Other indexes by Ottemiller, Logasa, etc., will still be necessary for the periods and special types covered.

This index is in four parts: I. The main list arranged by author, title, and subject; 2. a list of the 162 collections indexed; 3 . Cast analysis, a new feature listing each play under type of cast (male, female, mixed, puppet) and further by the number of characters; 4 . Directory of publishers.

All types of plays are indexed, the inclusiveness being determined by the collections that came to the attention of the editors.-K.L.

Ichikawa, Sanki, ed. The Kenkyusha Dictionary of English Quotations, with Examples of their Use by Modern Authors. Edited by Sanki Ichikawa, Masami Nishikawa [and] Mamoru Shimizu. Tokyo, Kenkyusha, 1952. 968p.

This "dictionary" lists 3170 common quota- 
tions from English literature, and gives about Io,00o examples of their use by modern English and American authors. An introductory essay contains statistics concerning the source of quotation, frequency of use, and manner of use.

The original quotations are arranged in 3 groups: I. those from the Bible, and the Book of Common Prayer, 2. those from Shakespeare, and 3. those from other English authors (arranged alphabetically by the quoted author). The title of the quoted work (with page or stanza), and the original quotation are in bold-face type, followed by the various uses of the quotation, with the quoter's surname, and, occasionally, forename or initials, and title and page. If the quotation has been used as a title, the year of publication is given. If quoted in a periodical, only the title of the latter, year and day are given.

There is an index to the original quotation, by first line or phrase, and by key-word. A "List of books quoted" (arranged alphabetically by author and giving no details except titles), and a list of periodicals show which authors and periodicals have used the quotations. There is no index to users of quotations.-M.C.

\section{BIOGRAPHY}

Quién es quién en Venezuela, Panamá, Ecuador, Colombia. Bogotá, Olivero Perry [1952- ] I074p. il.

Each country is separately treated, with biographical sketches of the Who's Who type alphabetically arranged; many of the entries are accompanied by small portraits of varying quality. Information is up to date as of June $30 t h, 1952$, and is based on previous publications of the same kind and on other national sources. There are lists of pseudonyms and of biographees by occupation, and an index-all divided by country and then arranged alphabetically. Some 5000 entries are included, and it will be a particularly useful work for its up-to-dateness and wide coverage.-O.J.

\section{GEOGRAPHY}

Arctic Institute of North America. Arctic Bibliography, prepared for and in cooperation with the Department of Defense. Wash., Govt. Prt. Off., 1953. 3v. \$1 2.75.
Prepared under the general direction of Marie Tremaine, this bibliography lists some 20,000 publications in many languages representing all phases of the subject, geographical, scientific and sociological. Emphasis is on the I9th and 2oth centuries.

In two parts: I. an alphabetical author list with full title in the original language, imprint and collation. Russian titles are given in LC transliteration. Translations into English are added for foreign titles. Entries include books, government documents, and periodical articles. There are brief annotations or abstracts and location is given for the copy used; 2. a comprehensive subject-geographic index of some 100,000 entries arranged under I 8,ooo subject and geographic headings. Annual cumulations are planned which will emphasize current publications.

World Directory of Geographers, published by the International Geographical Union. N.Y., I952. I67p.

Prepared with the financial assistance of UNESCO, this is a new directory listing the names of $35 \mathrm{I} 7$ professional geographers from some sixty countries. A professional geographer is defined as "one with special training in or scholarly contribution to the field, who devotes most of his time to geographic work." Part one, arranged alphabetically by country, gives, whenever possible, name of person, year of birth, present position, permanent mailing address, regional interests, systematic interests, other special interests. Part two is an index to the special interests.

\section{HISTORY}

\section{Morris, Richard B., ed. Encyclopedia of}

American History. N.Y., Harper, 1953. 776 p. il.

This is not an encyclopedia in the usual sense of the word, but rather a compendium of historical data, intended (as started in the preface) to be read as a narrative. Arrangement is in three main parts: I. a chronology of U.S. history, 2. a topical chronology covering such fields as population and immigration, American economy, thought and culture, 3 . biographical data on three hundred "notable Americans," both living and dead. The index covers all three sections and is exhaustive; there are some clear outline maps, particularly 
for the earlier periods, and a number of statistical tables. For libraries, this compilation will supplement but not replace other reference works in the field.-O.J.

Sztachova, Jirina, comp. Mid-Europe, a Selective Bibliography. N.Y., MidEuropean Studies Center of the National Committee for a Free Europe, 1953. I97p. (Mid-European Studies Center publication, no.Io)

I693 items (mainly books and monographs) covering the historical, political, economic, and cultural development of Central Europe are listed. The items are chiefly in Western languages slanted toward American readers and include only material published during the first half of this century. The book is divided into two main sections-the first part covers the general area arranged alphabetically under broad topics; the second part covers specific countries and regions with entries arranged alphabetically under each country or region. The entries are not annotated but cross references before each section are useful. An index to names of authors, editors and compilers referring to the number of the citation is included. A general subject index would have added value to the bibliography.F.G.

U.S. Library of Congress. Orientalia Division. Southeast Asia; an Annotated Bibliography of Selected Reference Sources, comp. by Cecil Hobbs, ref. lib. for Southeast Asia. Wash., 1952. I63p.

This monograph is prepared as a basic bibliography for information on Southeast Asia.
Main divisions are by country: Burma, Thailand, Indochina, Malaya, Indonesia, Philippines, and General. Sub-divisions under each country are: I. general background, 2. history, government and politics, 3. economics, 4. social conditions, and 5. cultural life. All items included are in Western languages. (Some unpublished theses are included.) Very complete information is given for each item; besides bibliographical data, texts, maps, illustrations, tables, etc., are described and appraised. In a few cases indications of locations other than Library of Congress are given.-B.S.

Wattenbach, Wilhelm. Deutschlands Geschichtsquellen im Mittelalter; Vorzeit und Karolinger, bearb. von Wilhelm Levison. Weimar, Hermann Böhlaus Nachfolger, 1952- pt.r.

Part $\mathrm{I}$ is a complete revision of the section of "Wattenbach," 7th ed., I904, (Guide V256) that concerns the sources of German history in the middle ages, from the beginnings up to the time of the Carolingians. It is in essay form with many foot-notes, and at the head of almost every subsection is a relevant bibliography listing source material and works about source material. Full bibliographical details are given for every book or periodical cited. Part $I$ has two main sections: I. a literary introduction with five subsections, each dealing with one literary grouping (e.g. 16th century works), and 2. a treatment of the material according to period or personage (e.g. Roman times, Gregory of Tours, etc.). There is a lengthy and useful list of abbreviations. An index lists persons, places, authors (or anonymous titles) of source materials.-M.C.

\section{Whitmaniana Wanted for Proposed National Depository}

The Walt Whitman Foundation of Brooklyn, Inc., which was created to establish and maintain a national depository of Walt Whitman materials, and which plans to lend these to scholars and the public, under suitable regulations, will welcome additions to its growing store of Whitman material, both manuscript and printed.

The Brooklyn College Library, which houses the Foundation, would be pleased to have any information about the location of fugitive Walt Whitman manuscripts in libraries and in the hands of private collectors or dealers. Please address inquiries to: H. G. Bousfield, chief librarian, Brooklyn College Library and executive director, Walt Whitman Foundation of Brooklyn, Inc., Brooklyn College, Brooklyn ro, New York. 